\title{
COLLECTION AND DESTRUCTION OF OLD ACCUMULATORS
}

\author{
Gintaras Virzonis \\ Accumulators Centre Ltd \\ Lithuania
}

Joint stock company "Accumulators Centre Ltd." is engaged in the field of Selling a "new-one" and Collecting an "old-one accumulators" - better called "BATTERIES", in Lithuanian Republic.

The company has 30 employes, Head office in Vilnius and 3 Semi-autonomic departments in Lithuanian towns: Vilnius, Plunge, Kedainiai also shop for selling Batteries in Panevezys city. The company represents in Lithuanian market "FIAMM GROUP" - Italian World famous batteries manufacturer.

The company is also engaged in a rather narrow, but very important field of Recycling - "Old Lead Acid Batterries and Lead Scrap Recycling".

The really technocratically "Buzzing" 20th century brought to our world, so do our little country, a big problem "CAR PROBLEM". For today, we have already more than million autowehicles in our country, that cause another seriuosly troubling problem - "Starter Batteries" problem. Obviously, everybody knows, that the car engine cannot start without a "Starter Power", that is accumulated in a "little box" called "Batterie", including Lead and Acid inside. So, the Problem appears!!!

In Lithuania with it's $3.7 \mathrm{mln}$ population, for today we have - $1.2 \mathrm{mln}$ "fleet of motor wehicles". More then 30 companies bring to Lihuania about 300.000 pieces of various Batteries per year. It means that together with "Polypropylene made monoblocks" is brought about 3.000 tones of Lead. You can imagine the quantities, nevertheless the official figures are very conraversal.

We perform it in a simple formula way:

\section{$1.200000=240.000 ;$}

\section{5}

1.200000 - The amount of autowehicles;

5 - The new car-Batterie medium life-years;

240.000 - The amount of old Batteries; 
So, you can realize, that every 5 years in Lithuanian appears the amount of 240.000 various types of old car Batteries.

Our analysis are based on 2 years experience, because during the last 2 years, "Accumulators Centre Ltd." company is very actively engaged not even in selling business area, but also in "collection of old Batteries" in our native land. As was mentioned above, our company has departments in other cities of Lithuania (Vilnius, Plunge, Kedainiai, Panevezys) - these are the points of collection an old Batteries.

Per year the company performs the collection about 25.000 pieces of various Batteries:

- SMALL CAR STARTER BATTERIES - 80\% of total amount;

- BIG CAR STARTER BATTERIES - $15 \%$ of total amount.

- FORKLIFT OR TRACTION BATTERIES - $4 \%$ of total amount.

- OTHERS - $1 \%$ of total amount.

The most total amount - $90 \%$ of collected Batteries are formed from "big" and "small" car Batteries.

We can proudly declare, that "Accumulators Centre Ltd.;" was the first and is the only one company for today in Lithuania that collect old Batteries together with electrolyte. The collected amount of electrolyte reaches above 100 tones per year.

The above mentioned "problem" could be solved by the recycling process, that mainly is divided in two parts: Destruction and Utilization.

For today, it is provided by our company in a little special factory near Kaunas city in a rather primitive and simple way. Because, unfortunately, "Ecologically Tested" old Batteries recycling technologies, as usually western companies made, are too much expensive for us.

For example: Italian company "Engitech Impianti Spa" offered us a compact recycling factory for recycling of old Batteries - a really "ecologically fantastic project "with a really "fantastic price" - $1.5 \mathrm{mln}$ USD... We suppose that it is a little big dream for a big future, nevertheless we are an optimists.

Whyle Destructing the old Batteries we receive:

1. LEAD PASTA - Contains $66 \%$ of Metal Lead $(\mathrm{Pb})$ content. This material represents about $40-50 \%$ on a dry basis of the total weight of the fed. Batteries. For today our company sends this product in a special package for recycling abroad

2. GRIDS AND POLES - Contain about $94 \%$ Metal content of $\mathrm{Pb}$ and represents about $25-30 \%$ on a dry basis of the total weight of the fed Batteries. The Lead ingots that are melted from that product are used as a second raw material.

3. POLYPROPYLENE - Contains about 97\% Polypropylene that represents about $5 \%$ of the Polypropylene case Batteries. That product is used as a second raw material. 
4. SEPARATORS AND EBONITE - are sent for disposal( because of not big amounts they as usually pass the dump utilization). This material represents about $5-7 \%$ amount of fed Batteries.

5. ELECTROLYTE - is collected and transported in a special plastic ( 50 litres amount) tankage to Kedainiai chemical plant "Lifosa" - the special place where is used in technological process of manufacturing of Phosphorious fertilizers.

Resume: Company "Accumulators Centre Ltd." during the last 2 years actively works for solution of the problem of recycling of old batteries. The crude analysis of the achieved results shows tbat an optimal solution of this problem must be found in the nearest future and based on technically approved experience and legislation. 